\title{
Environmental Conditions and COVID-19 Incident
}

\author{
Yura Witsqa Firmansyah ${ }^{1 *}$, Mirza Fathan Fuadi ${ }^{1}$, Farida Sugiester S. ${ }^{1}$, Wahyu Widyantoro \\ Muhammad Fadli Ramadhansyah ${ }^{2}$
}

1) Environmental Health Master Study Program, Faculty of Public Health, Diponegoro University, Semarang, Indonesia 2) Public Health Undergraduate Study Program, Environmental Health Concentration, Faculty of Public Health, Diponegoro University, Semarang, Indonesia

Yurawf14@gmail.com

DOI: http://doi.org/10.29080/ihsp.v5i1.514

Received : Februari 2021, Accepted: Maret 2021, Published: April 2021

\begin{tabular}{|c|c|}
\hline Keywords & Abstract \\
\hline $\begin{array}{l}\text { COVID-19; } \\
\text { Environmental } \\
\text { degradation; } \\
\text { Air pollution; } \\
\text { Climatology- } \\
\text { meteorology }\end{array}$ & 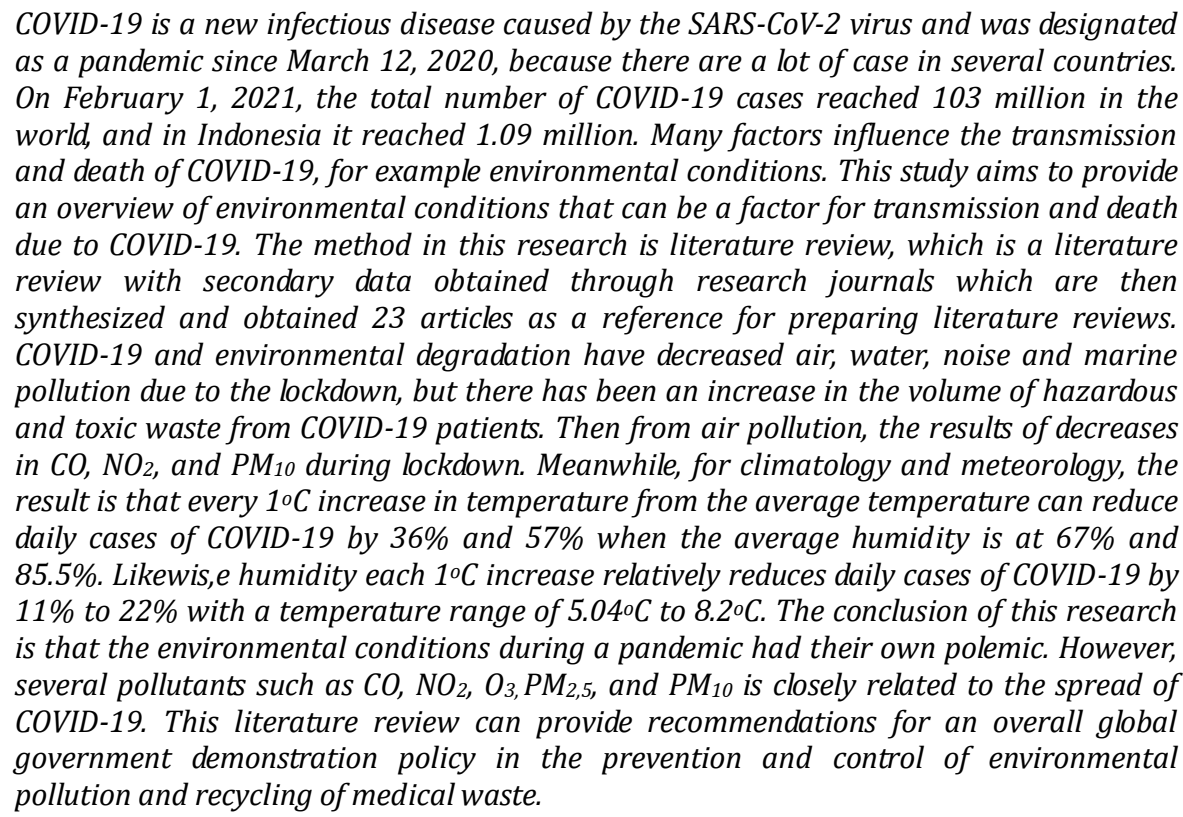 \\
\hline
\end{tabular}

\section{Introduction}

New pneumonia cases with unknown causes were reported from Wuhan, Hubei Province, China at the end of 2019. This case experienced rapid growth and development in the process of transmission to other provinces in China and several nearby countries such as Thailand and South Korea. The World Health Organization (WHO) announced on February 11, 2020, that the name of the disease, in this case, was Coronavirus Disease (COVID-19) which was caused by the 2019-nCoV virus until it turned into SARS-CoV2, which is a mutation of the SARS virus. On March 12, 2020, WHO declared COVID-19 as a pandemic state because of the rapid spread and transmission of cases in several other countries (1). The transmission of COVID-19 is very fast and within 3 weeks the spread of COVID-19 cases is increasing with more than 4 million cases worldwide with $3 \%$ of deaths. This figure continues to increase rapidly with the number of cases becoming 83 million worldwide and the death rate reaching 1.8 million (2). Meanwhile, on February 1 , the number of COVID-19 cases in Indonesia reached 1.09 million with 884 thousand recoveries and 30,227 deaths. (2). 
COVID-19 is transmitted mainly through aerosols, direct contact with sufferers and by spreading through droplets that can be inhaled by other people who are in close proximity to sufferers without wearing masks. Aerosol transmission of the COVID-19 virus can occur when respiratory droplets when coughing, sneezing or speaking are splashed into the air, forming aerosols and can cause infection if there is a large concentration of the virus in aerosols in the air. potential transmission routes for COVID-19 infection (1).

The transmission of COVID-19 through the environment has differences of opinion, but in the literature review, it is evident that environmental conditions have a significant effect on transmission and death due to COVID-19. Some environmental conditions that have a significant influence include climatology such as temperature, dew point, humidity, wind speed, rainfall on the transmission and death of COVID-19 (3),(4),(5),(6),(7),(8). Another environmental condition is air pollution, some studies say air pollution still has a moderate role (found positive, negative, and insignificant transmission of COVID-19 (9),(10),(11),(12). However, air pollution is an important and considered indicator of transmission and death due to COVID-19 (13),(14),(15). Because of the description above, writing this literature review aims to provide an overview of environmental conditions that can be a factor of transmission and death due to COVID-19.

\section{Methods}

This writing uses the literature review method, which is a literature review with secondary data studies obtained from various research journals indexed in Scopus quartile 1 (Q1) so that the quality of the review journals produced is of high quality. The entire journal literature from Q1 is then filtered by applying inculsion and exclusion criteria in order to narrow the study space. The journal inclusion criteria used are:

1. Published in quartile 1 (Q1)

2. Published year 2019-2020

3. Has a COVID-19 research theme

4. Has significant environmental factors or environmental conditions.

The journal exclusion criteria used are:

1. Published not in quartile 1 (Q1) but has a COVID-19 theme

2. Some environmental factors or environmental conditions are of significant value and some are not.

As many as 57 research journals were obtained, but after synthesizing with inclusion and exclusion criteria, 23 journals were used as references in the following literature review. Obtained qualitative and quantitative data are analyzed systematically in order to obtain a concluding study of the discussion that represents the entire contents of the literature review.

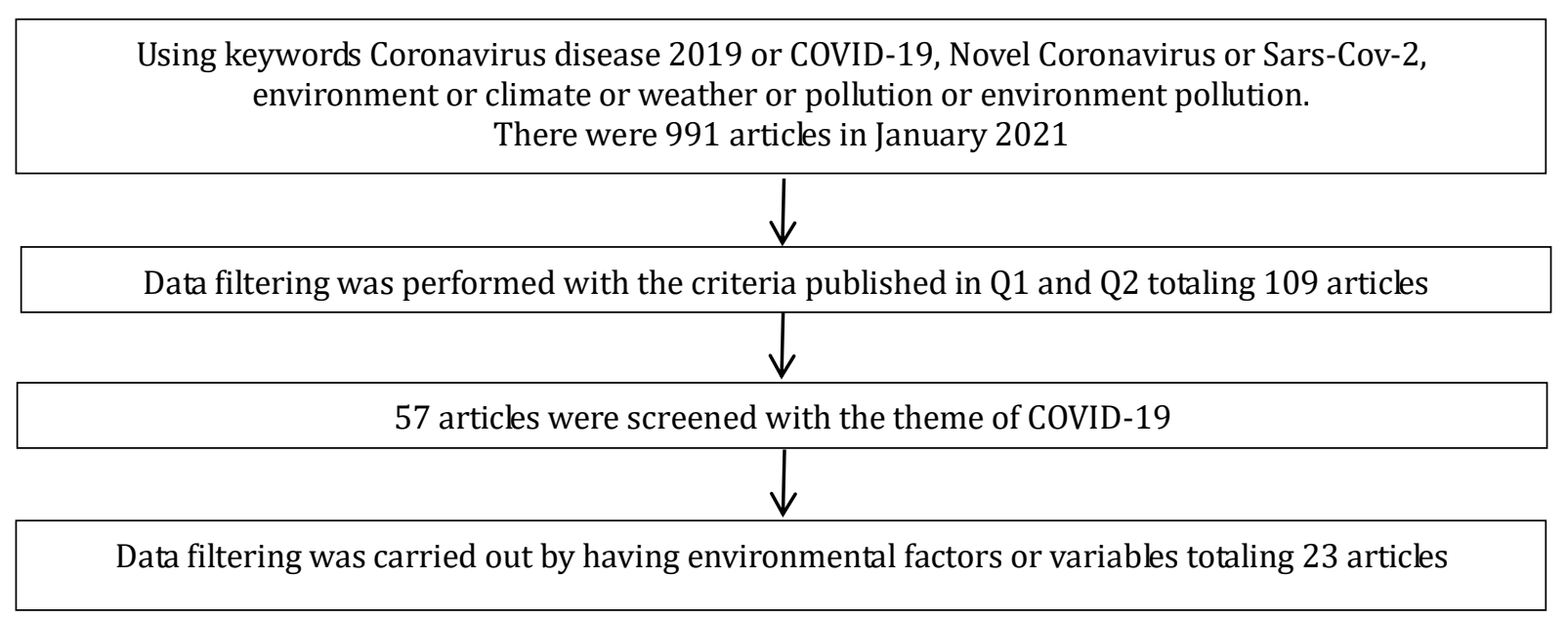

Figure 1. Flowchart of Systematic Literature Search 


\section{Results}

\section{Journal Identification and Synthesis}

Table 1. Journal Synthesis Result

\begin{tabular}{ll}
\hline \multicolumn{1}{c}{ Researcher (year) } & \multicolumn{1}{c}{ Findings } \\
\hline Qiang Wang, Min Su. & 1) Significant reduction in air pollution \\
(2020) & $\begin{array}{l}\text { due to full or partial lockdown in the } \\
\text { short term, resulting in GHG reduction }\end{array}$ \\
& 2) The findings do not support GHG \\
& reduction in the long term because, \\
after the removal of the lockdown, & economic activity and traffic will be \\
& higher, which could result in more \\
& energy consumption and higher GHG \\
& emissions. \\
\hline Zambrano-Monserrate, & $\begin{array}{l}\text { COVID-19 improves air quality, } \\
\text { beaches and reduces noise levels as }\end{array}$ \\
& well as increases the amount of \\
domestic and medical waste and low- & cost initiatives to recycle waste \\
1) GHG reduction for a shorter period & of time
\end{tabular}

\begin{tabular}{|c|c|c|c|}
\hline $\begin{array}{l}\text { Chakraborty, I., Maity, P., } \\
(2020)\end{array}$ & $\begin{array}{l}\text { COVID-19 helps restore } \\
\text { environmental conditions and has a } \\
\text { positive effect on the environment }\end{array}$ & Global & (18) \\
\hline $\begin{array}{l}\text { Saadat, S., Rawtani, D., } \\
\text { Hussain, CM, (2020) }\end{array}$ & $\begin{array}{l}\text { 1) Improve air and water quality } \\
\text { around the world } \\
\text { 2) Increase in large quantities of } \\
\text { medical waste }\end{array}$ & Global & (16) \\
\hline $\begin{array}{l}\text { Abdullah, S., Mansor, AA, } \\
\text { Napi, NNLM, Mansor, } \\
\text { WNW, Ahmed, AN, } \\
\text { Ismail, M., Ramly, ZTA, } \\
(2020)\end{array}$ & $\begin{array}{l}\text { Finds the significant effect of MCO } \\
\text { Malaysia on the reduction of } \mathrm{PM}_{2.5}\end{array}$ & Malaysia & (13) \\
\hline $\begin{array}{l}\text { Dantas, G., Siciliano, B., } \\
\text { França, BB, da Silva, CM, } \\
\text { Arbilla, G., (2020) }\end{array}$ & $\begin{array}{l}\text { 1) } \mathrm{CO} \text { decreased significantly during } \\
\text { lockdown } \\
\text { 2) } \mathrm{NO}_{2} \text { and } \mathrm{O}_{3} \text { have decreased } \\
\text { 3) } \mathrm{PM}_{10} \text { fell to a lower level }\end{array}$ & $\begin{array}{l}\text { Rio de Janeiro, } \\
\text { Brazil }\end{array}$ & $(20)$ \\
\hline $\begin{array}{l}\text { Muhammad, S., Long, X., } \\
\text { Salman, M., (2020) }\end{array}$ & $\begin{array}{l}\text { Air pollution reduced by about } 30 \% \\
\text { during COVID-19 Mobility reduced by } \\
90 \%\end{array}$ & $\begin{array}{l}\text { China, Spain, } \\
\text { France, Italy and } \\
\text { USA }\end{array}$ & (15) \\
\hline $\begin{array}{l}\text { Tobías, A., Carnerero, C., } \\
\text { Reche, C., Massagué, J., } \\
\text { Via, M., Minguillón, MC, } \\
\text { Alastuey, A., Querol, X., } \\
(2020)\end{array}$ & $\begin{array}{l}\text { 1) } \mathrm{NO}_{2} \text { and } \mathrm{BC} \text { are reduced by about } \\
50 \% \text { during lockdown } \\
\text { 2) } \mathrm{PM}_{10} \text { is reduced } \\
\text { 3) } \mathrm{O}_{3} \text { increased by } 50 \% \text { during } \\
\text { lockdown }\end{array}$ & Barcelona, Spain & $(20)$ \\
\hline $\begin{array}{l}\text { Bashir, MF, Ma, B., Bilal, } \\
\text { Komal, B., Bashir, MA, } \\
\text { Tan, D., Bashir, M., } \\
(2020)\end{array}$ & $\begin{array}{l}\text { Minimum average temperature and air } \\
\text { quality have a significant effect on the } \\
\text { transmission of COVID-19 }\end{array}$ & $\begin{array}{l}\text { New York City, } \\
\text { USA }\end{array}$ & (17) \\
\hline $\begin{array}{l}\text { Tosepu, R., Gunawan, J., } \\
\text { Effendy, DS, Ahmad, } \\
\text { LOAI, Lestari, H., Bahar, } \\
\text { H., Asfian, P., (2020) }\end{array}$ & $\begin{array}{l}\text { Average temperatures significantly } \\
\text { affect transmission of COVID-19 }\end{array}$ & Jakarta, Indonesia & (18) \\
\hline Şahin, M., (2020) & $\begin{array}{l}\text { 1) Wind is positively related to COVID- } \\
19 \text { cases } \\
\text { 2) City crowds are positively } \\
\text { associated with COVID-19 infection }\end{array}$ & Turkey & (6) \\
\hline $\begin{array}{l}\text { Zhu, Y., Xie, J., Huang, F., } \\
\text { Cao, L., (2020) }\end{array}$ & $\begin{array}{l}\text { 1) The positive relationship between } \\
\text { PM2.5, PM10, CO, NO2 and O3, on the } \\
\text { transmission of COVID-19 } \\
\text { 2) There is no significant relationship } \\
\text { between SO2 and the transmission of } \\
\text { COVID-19 }\end{array}$ & China & $(8)$ \\
\hline
\end{tabular}


Table 1. Journal Synthesis Result (cont)

\begin{tabular}{|c|c|c|c|}
\hline Researcher (year) & Findings & Sample & Reference \\
\hline $\begin{array}{l}\text { Qi, H., Xiao, S., Shi, R., } \\
\text { Ward, MP, Chen, Y., Tu, } \\
\text { W., Su, Q., Wang, W., } \\
\text { Wang, X., Zhang, Z., ( } \\
\text { 2020) }\end{array}$ & $\begin{array}{l}\text { 1) The insignificant effect of } \\
\text { temperature and humidity on daily } \\
\text { cases of COVID-19 } \\
\text { 2) The effect of the strong interaction } \\
\text { between temperature and humidity on } \\
\text { daily cases of COVID-19 }\end{array}$ & $\begin{array}{l}30 \text { Chinese } \\
\text { provinces }\end{array}$ & (5) \\
\hline $\begin{array}{l}\text { Gupta, S., Raghuwanshi, } \\
\text { GS, Chanda, A., (2020) }\end{array}$ & $\begin{array}{l}\text { Temperature and humidity can predict } \\
\text { transmission of COVID-19 in the US }\end{array}$ & US & (23) \\
\hline $\begin{array}{l}\text { Ma, Y., Zhao, Y., Liu, J., He, } \\
\text { X., Wang, B., Fu, S., Yan, J., } \\
\text { Niu, J., Zhou, J., Luo, B., } \\
(2020)\end{array}$ & $\begin{array}{l}\text { 1) A positive and significant } \\
\text { correlation between temperature and } \\
\text { daily deaths from COVID-19 } \\
\text { 2) Negative correlation between } \\
\text { humidity and cases of death from } \\
\text { COVID-19 }\end{array}$ & Wuhan, China & (3) \\
\hline $\begin{array}{l}\text { Sobral, MFF, Duarte, GB, } \\
\text { da Penha Sobral, AIG, } \\
\text { Marinho, MLM, de Souza } \\
\text { Melo, A., } 2020\end{array}$ & $\begin{array}{l}\text { 1) Negative relationship between } \\
\text { temperature and transmission of } \\
\text { COVID-19 } \\
\text { 2) Positive relationship between } \\
\text { rainfall and transmission of COVID-19 } \\
\text { 3) Countries with high rainfall will } \\
\text { also have higher transmission of } \\
\text { COVID-19 } \\
\text { 4) There is no relationship between } \\
\text { rainfall or temperature and cases of } \\
\text { COVID-19 deaths }\end{array}$ & $\begin{array}{l}\text { Global } \\
\text { (international) }\end{array}$ & (7) \\
\hline Ogen, Y., 2020 & $\begin{array}{l}\text { Prolonged exposure to NO2 increases } \\
\text { deaths from COVID-19 }\end{array}$ & $\begin{array}{l}\text { Italy, Spain, France } \\
\text { and Germany }\end{array}$ & $(24)$ \\
\hline $\begin{array}{l}\text { Briz-Redón, Á., Serrano- } \\
\text { Aroca, Á., (2020) }\end{array}$ & $\begin{array}{l}\text { There was no significant relationship } \\
\text { between temperature and the } \\
\text { transmission of COVID-19 }\end{array}$ & Spain & (9) \\
\hline $\begin{array}{l}\text { Prata, DN, Rodrigues, W., } \\
\text { Bermejo, PH, (2020) }\end{array}$ & $\begin{array}{l}\text { At an average temperature below } \\
25.8^{\circ} \mathrm{C} \text {, each } 1^{\circ} \mathrm{C} \text { increase is } \\
\text { associated with a }-4.895 \% \text { decrease in } \\
\text { confirmed COVID-19 cases per day }\end{array}$ & Brazil & $(10)$ \\
\hline Xie, J., Zhu, Y., (2020) & $\begin{array}{l}\text { The negative relationship between } \\
\text { temperature and transmission of } \\
\text { COVID- } 19 \text { when temperatures are } \\
\text { between } 16.8^{\circ} \mathrm{C} \text { and } 27.4^{\circ} \mathrm{C}\end{array}$ & China & (12) \\
\hline $\begin{array}{l}\text { Jahangiri, M., Jahangiri, } \\
\text { M., Najafgholipour, M., } \\
(2020)\end{array}$ & $\begin{array}{l}\text { Temperature reduces cases of COVID- } \\
19 \text { transmission }\end{array}$ & Iran & (25) \\
\hline $\begin{array}{l}\text { Shi, P., Dong, Y., Yan, H., } \\
\text { Zhao, C., Li, X., Liu, W., He, } \\
\text { M., Tang, S., Xi, S., (2020) }\end{array}$ & $\begin{array}{l}\text { 1) Temperature shows a positive } \\
\text { linear relationship with COVID-19 } \\
\text { cases when the temperature is lower } \\
\text { than } 3^{\circ} \mathrm{C} \\
\text { 2) There was no evidence of cases of } \\
\text { transmission of COVID-19 due to } \\
\text { increased temperatures } \\
\text { 3) Temperatures above around } 8 \text { to } \\
10^{\circ} \mathrm{C} \text { have a chance of reducing the } \\
\text { incidence of COVID-19 }\end{array}$ & China & (11) \\
\hline $\begin{array}{l}\text { Pirouz, B., Haghshenas, } \\
\text { SS, Pirouz, B., } \\
\text { Haghshenas, SS, Piro, P., } \\
2020 .\end{array}$ & $\begin{array}{l}\text { Climatic factors influence trends in } \\
\text { confirmed cases of COVID-19 }\end{array}$ & Italy & (4) \\
\hline
\end{tabular}

The literature review used was 23 with the content of the relationship between COVID-19 and environmental conditions. Then the environmental conditions are classified into 3 clusters, namely environmental degradation, air pollution, climatological-meteorological factors. Research samples in journals that are used as literature reviews are global or international so that they can reflect the overall problem of environmental conditions on the incidence of COVID-19. 


\section{Discussion \\ COVID-19 and Environmental Degradation}

COVID-19 has had a negative impact in almost all fields, economy, socio-community, and of course health. However, in the environmental sector, COVID-19 has a positive impact by reducing environmental damage (19). Environmental damage such as greenhouse gas (GHG) emissions, air pollution due to nitrogen dioxide $\left(\mathrm{NO}_{2}\right)$ gas pollutants, water pollution, noise and pollution at sea have decreased significantly due to total or partial lockdowns in China, USA, Italy and Spain. $(16,17,18,19)$. The application of restrictions (lockdowns) in several countries can help reduce environmental pollution so as to produce good clean air quality (19). However, the findings on greenhouse gas emissions were only reduced during lockdown conditions or not in the long term, because after the lockdown was removed, large-scale industrial conditions and activities, the use of fuels that produced gaseous pollutants that impacted greenhouse gas emissions increased again. (20).

In addition, other findings explain that the lockdown has an indirect effect, such as decreasing noise and pollution at sea and increasing air quality. Noise due to massive industrial activities has a negative impact on public health and the sustainability of natural ecosystems(21). Likewise with pollution on the beach, the salinity on the coast of Acapulco, Barcelona is drastically reduced and the water conditions are clear due to low tourist visits (17). Meanwhile, the total lockdown had an effect of $\mathrm{NO}_{2}$ and $\mathrm{PM}_{2.5}$ in Wuhan, China by $22.8 \mu \mathrm{g} / \mathrm{m} 3$ and $1.4 \mu \mathrm{g} / \mathrm{m}^{3}$ so that clean air production increased.

Environmental damage also still occurs, domestic waste and medical waste that are hazardous and toxic in nature have the potential to be a source of disease transmission due to COVID-19 patients who are not properly treated. For example in Wuhan, 240 metric tons of medical waste was generated per day from hospitals compared to before the COVID-19, which only produced 50 tons per day(17). Domestic or household waste has also increased due to online shopping activities and delivery from home(17). Efforts to stabilize environmental pollution levels at low levels need to be carried out again after the lockdown and treatment of medical waste due to COVID-19 patients, proper treatment efforts must be made to prevent transmission of the corona virus due to COVID-19.

Follow-up for research, it is necessary to study other variables or factors such as weather, partial or total industrial operations, traffic, as well as studies of other pollutants such as $\mathrm{SO}_{2}$, total dust, or other pollutants.

\section{COVID-19 and Air Pollution}

Air pollution is still a serious problem in providing health effects as well as a major cause of death. Air pollution caused 4.9 million deaths worldwide in 2017. Low-income economies are at the greatest risk (22). Regarding COVID-19, significant results were found in the implementation of lockdown in reducing air pollution(23). Air pollutants such as $\mathrm{NO}_{2}$ and $\mathrm{CO}_{2}$ emissions gas have decreased significantly, as a result of the shutdown of industrial operations(28). The consumption of fossil fuels has also decreased, so that air pollution in several countries has also decreased, such as China, Italy, the United States and India(24). India, in major cities such as Ahmedabad, Mumbai and Pune saw a decrease of $40-50 \%$ during the lockdown process(25). In Europe, carbon dioxide (CO2) pollutants also decreased by 390 million tonnes due to lockdowns(28). Whereas in the United States, carbon emissions decreased by $40 \%$ during lockdown due to low traffic activity (24).

Another study also explained that carbon monoxide (CO), $\mathrm{NO}_{2}$, and particulate matter with a diameter of $10 \mu \mathrm{m}$ ' $\left(\mathrm{PM}_{10}\right)$ had decreased significantly during the global lockdown. As a result, ozone $\left(\mathrm{O}_{3}\right)$ has increased due to a decrease in $\mathrm{NO}_{2}(26)$. Research that is also in line is, it was found that $\mathrm{NO}_{2}$ and black carbon (BC) were reduced by $50 \%$ during the lockdown period, while $\mathrm{PM}_{10}$ decreased within a certain time limit (20). Ozone pollutants $\left.\mathrm{O}_{3}\right)$ increased by more than $50 \%$ during the lockdown in Barcelona, while $\mathrm{NO}_{2}$ decreased by $45 \%$ and BC by 51\% (20) Air pollution in Malaysia found that movement control order (MCO) had a significant effect on reducing $\mathrm{PM}_{2,5}$ (13) whereas air pollution was reduced by $30 \%$ with mobility down by almost $90 \%$ in another study (15).

Follow-up research requires a study of meteorological factors, testing the effect of lockdown on air quality, and exploring the low value of $\mathrm{PM}_{10}$ compared to other pollutants such as $\mathrm{NO}_{2}$ and $\mathrm{BC}$.

\section{COVID-19 and Climatology-Meteorology Factors}

COVID-19 is the same disease as other infectious diseases that are influenced by climatic factors. Meteorological or climatic factors such as temperature, humidity, rainfall and wind speed have a significant influence on infectious diseases including COVID-19. One study found that meteorological factors have a significant effect on COVID-19 (27). Air quality conditions have also significantly increased the spread of the corona virus in New York City (21). In addition, weather and meteorological factors also have a significant influence on the transmission of COVID-19 in Turkey and China(6,8). Meteorological factors of wind speed are reported to have a positive association value with COVID-19 in cities with high 
transmission cases(6). Other studies have also found that $\mathrm{PM}_{2,5}, \mathrm{PM}_{10}, \mathrm{CO}, \mathrm{NO}_{2}$ and $\mathrm{O}_{3}$ pollutants have a significant relationship with COVID-19 transmission, while NO2 pollutants have a negative association value with COVID-19 transmission. (8).

The conditions of the COVID-19 pandemic provide interest for researchers in examining factors related to the transmission of COVID-19 including climate factors (28). Climatic factors were found to be one of the factors that disrupt the trend of transmission of COVID-19(4). Meanwhile, meteorological factors such as temperature and humidity have validity in cases of COVID-19 in 30 provinces in China (5). In the study, it was explained that temperature and humidity had a bad influence on the significance of daily cases of COVID-19, and temperature and humidity had a strong association with daily cases of COVID19(5). Each $1^{\circ} \mathrm{C}$ increase in temperature can reduce daily cases of COVID-19 by $36 \%$ and $57 \%$ when the average humidity is at $67 \%$ and $85.5 \%$. Likewise humidity, each $1{ }^{\circ} \mathrm{C}$ increase relatively reduces daily cases of COVID-19 by $11 \%$ to $22 \%$ with a temperature range of $5.04{ }^{\circ} \mathrm{C}$ to $8.2{ }^{\circ} \mathrm{C}$ (5). To going forward, temperature and humidity can project and predict the transmission of COVID-19 in the United States (23).

Table 2. Temperature Projection of COVID-19 Transmission

\begin{tabular}{ll}
\hline \multicolumn{1}{c}{ Temperature Analysis } & Transmission of COVID-19 \\
\hline Temperature $<3^{\circ} \mathrm{C}$ & Increase the risk of transmitting COVID-19 \\
Temperature $>8^{\circ} \mathrm{C}$ & Reducing the risk of transmitting COVID-19 \\
\hline
\end{tabular}

Other studies explain that climatic factors on indicators of COVID-19 transmission have different points of view. The relationship between climatic factors is still positive and negative in COVID-19 deaths $(3,7)$. The effect of meteorological factors on COVID-19 mortality and mortality has a positive significant association value but in diurnal temperature conditions, and a negative association between humidity and COVID-19 mortality. (3). Research on $\mathrm{NO}_{2}$ pollutants, COVID-19 deaths in Italy, Spain, Germany, and France using spatially, that long-term $\mathrm{NO}_{2}$ exposure affects the increase in COVID-19 deaths(29). Temperature or rainfall factors were not found to be associated with deaths due to COVID-19(7). Even though the climatological and meteorological factors have different research results, it is hoped that they can take into consideration the prevention and control of COVID-19.

As a follow-up to the research, it is necessary to study the climatological and meteorological factors of many countries. Because every country has different climatological and meteorological aspects. It also needs consideration of other factors such as discipline, tightness of regulations and the health service system.

\section{Conclusion}

The environmental conditions at the time of the COVID-19 pandemic had their own polemic. Environmental damage such as air and sea pollution has begun to decrease with the lockdown policy as an effort to prevent and control COVID-19. However, several pollutants such as $\mathrm{CO}, \mathrm{NO}_{2}, \mathrm{O}_{3}, \mathrm{PM}_{2,5}$, and $\mathrm{PM}_{10}$, have a association with the transmission of COVID-19. In addition, climatic and meteorological factors (such as temperature and humidity) are strongly associated with daily COVID-19 cases. This study has limited time, the publication time which is used as a literature journal is November 2019-May 2020. This research also lacks articles on the theme of environmental degradation related to COVID-19. Most of the articles used on environmental degradation are climate change. This literature review can provide recommendations regarding a holistic model policy for governments globally in efforts to prevent and control environmental pollution, and recycle medical waste.

\section{Acknowledgments}

Thank you to the Faculty of Public Health, Diponegoro University for supporting us during the process of writing articles. Hopefully this article can be useful for many people and can be a reference in making literature reviews.

\section{References}

1. Susilo A, Rumende CM, Pitoyo CW, Santoso WD, Yulianti M, Herikurniawan H, et al Coronavirus Disease 2019: Tinjauan Literatur Terkini. J Penyakit Dalam Indones. 2020;7(1):45.

2. Organization WH. Data Report COVID-19. Switzerland; 2020.

3. Ma Y, Zhao Y, Liu J, He X, Wang B, Fu S, et al. Effects of temperature variation and humidity on the mortality of COVID-19 in Wuhan. medRxiv. 2020;

4. Pirouz B, Haghshenas SS, Pirouz B, Haghshenas SS, Piro P. Development of an assessment method 
for investigating the impact of climate and urban parameters in confirmed cases of COVID-19: A new challenge in sustainable development. Int J Environ Res Public Health. 2020;17(8).

5. Qi H, Xiao S, Shi R, Ward MP, Chen Y, Tu W, et al COVID-19 transmission in Mainland China is associated with temperature and humidity: a time-series analysis. 2020;

6. Şahin M. Impact of weather on COVID-19 pandemic in Turkey. Sci Total Environ. 2020;728:138810.

7. Felipe M, Sobral F, Benini G, Iza A, Sobral P, Luiz M, et al. Association between climate variables and global transmission oF SARS-CoV-2. 2020;(January).

8. Zhu Y, Xie J, Huang F, Cao L. Association between short-term exposure to air pollution and COVID-19 infection: evidence from China. 2020;(January).

9. Briz-redón Á, Serrano-aroca Á. spatio-temporal analysis for exploring the effect of temperature on COVID-19 early evolution in Spain. 2020;(January).

10. Prata DN, Rodrigues W, Bermejo PH. Temperature significantly changes COVID19 transmission in (sub)tropical cities of Brazil. 2020;(January).

11. Shi P, Dong Y, Yan H, Zhao C, Li X, Liu W, et al Impact of temperature on the dynamics of the COVID19 outbreak in China. 2020;(January).

12. Xie J, Zhu Y. Association between ambient temperature and COVID-19 infection in 122 cities from China. 2020;(January).

13. Abdullah S, Abu A, Nazmi N, Mohd L, Nurdiyana W, Mansor W. Air quality status during 2020 Malaysia Movement Control Order (MCO) due to 2019 novel coronavirus (2019-nCoV) pandemic. Sci Total Environ. 2020;729(January):139022.

14. Carrington D. Air pollution linked to far higher Covid-19 death rates, study finds. 2021.

15. Muhammad S, Long X, Salman M. COVID-19 pandemic and environmental pollution: a blessing in disguise? 2020;(January).

16. Saadat S, Rawtani D, Hussain CM. Environmental perspective of COVID-19. Sci Total Environ. 2020;728:138870.

17. Bashir MF, Ma B, Bilal, Komal B, Bashir MA, Tan D, et al. Correlation between climate indicators and COVID-19 pandemic in New York, USA. Sci Total Environ. 2020;728:138835.

18. Tosepu R, Gunawan J, Savitri D, Ode L, Imran A, Lestari H. Correlation between weather and Covid19 pandemic in Jakarta, Indonesia. Sci Total Environ. 2020;(January).

19. Chakraborty, I., Maity P. COVID-19 outbreak: migration, effects on society, global environment and prevention. 2020;(January).

20. Wang Q Su M. A preliminary assessment of the impact of COVID-19 on environment - a case study of China. 2020;(January).

21. Zambrano-monserrate MA, Alejandra M, Sanchez-alcalde L. Indirect effects of COVID-19 on the environment. 2020;(January).

22. Global Burden of Disease Study 2017. Global Burden of Disease Study 2017. Lancet. 2017;5:1-27.

23. Tobías A, Carnerero C, Reche C, Massagué J, Via M, Minguillón MC, et al. Changes in air quality during the lockdown in Barcelona (Spain) one month into the SARS-CoV-2 epidemic. 2020;(January).

24. Paital B, Das K, Parida SK. Inter nation social lockdown versus medical care against COVID-19, a mild environmental insight with special reference to India. Sci Total Environ. 2020;728:138914.

25. Wright R. The world's largest coronavirus lockdown is having a dramatic impact on pollution in India [Internet]. 2020. Available from: https://edition.cnn.com/2020/03/31/asia/coronaviruslockdown-impact-pollution-india-intl-hnk/index.html

26. Dantas G, Siciliano B, Boscaro B, Cleyton M, Arbilla G. The impact of COVID19 partial lockdown on the air quality of the city of Rio de Janeiro, Brazil. 2020;(January).

27. Jahangiri $M$, Jahangiri $M$, Najafgholipour $M$. The sensitivity and specificity analyses of ambient temperature and population size on the transmission rate of the novel coronavirus (COVID-19) in different provinces of Iran. 2020;(January).

28. Gupta S, Singh G, Chanda A. Effect of weather on COVID-19 spread in the US: a prediction model for India in 2020. 2020;(January).

29. Ogen Y. Assessing nitrogen dioxide (NO2) levels as a contributing factor to coronavirus (COVID-19) fatality. 2020;(January). 